\title{
Solid-state diffusion bonding of closed-cell aluminum foams
}

\section{クローズドセル型アルミニウムフォームの固相拡散接合}

\author{
Akiko KITAJIMA and Jun-ichi MATSUSHITA \\ Department of Applied Chemistry, School of Engineering, Tokai University, 1117 Kitakaname, Hiratsuka, \\ Kanagawa 259-1292, Japan
}

TEL: 81-463-58-1211 (ext.4186) FAX: 81-463-50-2012

\section{Koichi KITAZONO, Eiichi SATO and Kazuhiko KURIBAYASHI}

The Institute of Space and Astronautical Science, 3-1-1 Yoshinodai, Sagamihara, Kanagawa, 229-8510, Japan

TEL: 81-42-759-8266 FAX: 81-42-759-8461

(Received 19, November 2001 Accepted 26, July 2002)

Solid-state diffusion bonding(DB)was demonstrated for joining closed-cell aluminum foams(ALPORAS). A superplastic 5083 aluminum alloy sheet was inserted between the foams to assist the DB process. Microscopic observation revealed that the cell wall of the foams penetrated into the 5083 alloy sheet and their interface partly disappeared. Energy dispersion X-ray spectrometer(EDS) confirmed the diffusion of magnesium element from the 5083 alloy to the aluminum foam regions. The bonding strength was evaluated by four-point bend tests. The obtained bending stress was about $50 \%$ of the original foam at room temperature and was more than $60 \%$ at $423 \mathrm{~K}$. The advantage of the $\mathrm{DB}$ process in the high temperature applications was discussed comparing with the adhesive bonding of aluminum foams.

Keywords: Aluminum foam; 5083 Al-Mg alloy; Superplasticity; Diffusion bonding; Bending test

\section{I . INTRODUCTION}

昔から断熱材や緩衝材として使用されている多孔質 材料（セル構造体）は， 2 次元の構造を有するハニカ ムと 3 次元の構造を有するフォーム (発泡体) に大別 される。これまでに棟瓦のようなセラミックスフォー ム、発泡スチロールのようなポリマーフォームが存在 したが、金属フォームはポリマーフォームよりも耐熱 性、不然性、加工性に優れ、塑性変形により非常に大 きなエネルギーを吸収することができるため、最近注 目されている。

金属フォームは、切削、曲げ、圧延といった加工性 に優れているが、接合性に関しては、普通の緻密金属 材料よりも劣っている。リベット接合では場所により 緩む可能性があり、ろう付やはんだ付け、化学接着斉 による接着はフォームの使用上限温度が制限されてし まう。フォームの最も大きな需要が、断熱材料として の使用であることからもこの方法のみに頼るわけには いかない。また、金属フォームは溶解させると体積が 減少し、セル構造が失われてしまうため、溶接がほと んど不可能である。以上のような理由から金属フォー 么の接合には固相搪散接合が有効と考えられる。一般 的な固相拡散接合の場合、界面の酸化皮膜を破壊する ための塑性変形を得るために大きな圧縮応力が必要で
あるが、フォームは壊れやすいため、本研究ではイン サートした微細粒超塑性材料の低応力下での大ひずみ を利用することにより、できるだけセル構造を維持し た金属フォームの固相拡散接合を試みた。

\section{EXPERIMENTAL PROCEDURE}

神鋼鋼線株式会社製のクローズドセル型アルミニウ ムフォーム (ALPORAS) 1 （相対密度 0.11）と厚さ $1 \mathrm{~mm}$ の超塑性 5083 アルミニウム合金圧延板 ${ }^{2}$ を用意した。 両者の表面を鏡面研磨し、エタノール中で超音波洗浄 後、Keller 試薬を用い化学研磨を行った。その後、 5083A1 を接合面にインサートした試験片を作製した。 試験は大気中にて行われ 1 巻のコイルを用いて接合界 面を局所的に誘導加熱した。このときの温度はALPORAS が緻密化せず 5083A1 が超塑性を示す $773 \mathrm{~K}$ ～ $823 \mathrm{~K}$ に 設定し、0.2MPa の外部応力を $10 \mathrm{~min}$ 付加した。

接合試験後、接合面を光学顕微鏡とSEM を用いて観 察した。また、島津製オートグラフを用いて室温、423 K でクロスヘッドスピード $0.5 \mathrm{~mm} / \mathrm{min}$ で 4 点曲け試験 を行い機械的特性を評価した。

\section{RESULTS AND DISCUSSION}


$823 \mathrm{~K} 、 0.2 \mathrm{MPa}$ 、大気中で $10 \mathrm{~min}$ 接合試験を行った 接合面の光学顕微鏡写真をFig. 1 に示す。5083AI の超 塑性変形に伴うて、ALPORAS のセル壁が楔のように 5083A1 に押しこまれており、楔の先端部分において両 者吕接合していた。

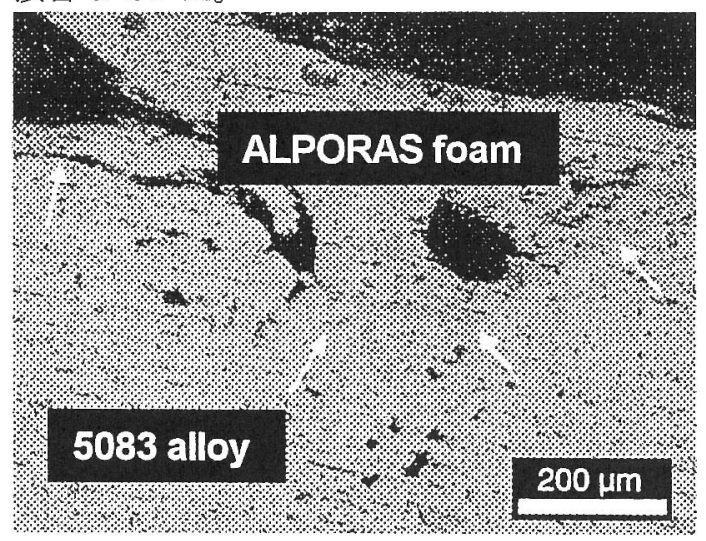

Fig.1. Longitudinal section of bonding interface.

接合した縦断面を鏡面研摩した後、加速電王 $5 \mathrm{kV}$ で ALPORAS 粒内の，SEMによるEDS 分析を行った。

Figure2 に界面付近の Mg 濃度の変化を示す。5083A] の $\mathrm{Mg}$ 濃度は約 5.8wt\%であり、界面から離れるにつれ てMg 濃度が減少して行くのがわかる。5083A1 のみに しか唅まれていない Mg が ALPORAS からも観察された。 これ住 ALPORAS 一 Mg 原子が拡散したことを意味する。 A. 中の Mg の拡散係数は $1.82 \times 10^{-5}$ であり、活性化工 ネルギーは $131 \mathrm{kj} / \mathrm{mol}$ である。また，平衡状態図より 接合温度では液相は生じていない。

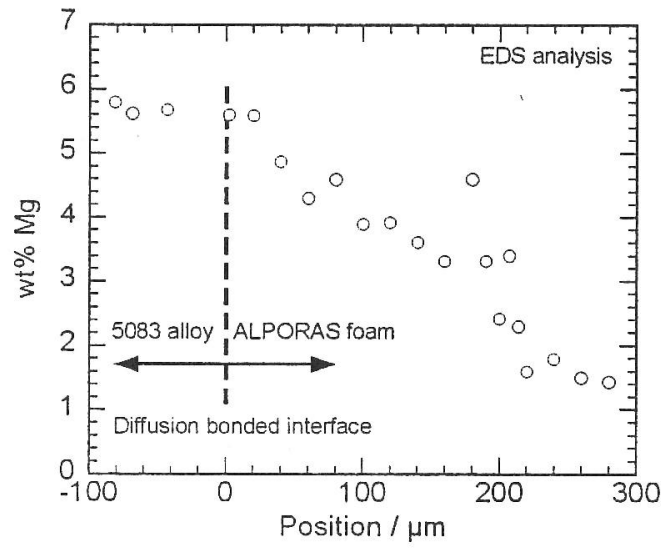

Fig.2. Composition of $\mathrm{Mg}$ element measured by EDAX/EDS system.

4 点曲げ試験の結果を Fig.3 に示寸。最大荷重から曲 げ強度を求めた。固相搪散接合、化学系接着剂で接合 した材料は全て、接合面において破断した。 $423 \mathrm{~K} に$ おいて、エポキシ系、ポリエチレン系接着剤を用い接 着した試験片は土室温と比べると汢曲げ強度が著しく減 少している。しかし、773 K、823 K で固相拡散接合し
た材料は室温におらてても、423Kにおいてもほぼ同じ曲 げ強度を保ち、室温において母材の約 50\%、423K にお いて母材の約 $60 \%$ の強度を示した。このことから本接 合方法は、高温使用に適していると考えられる。
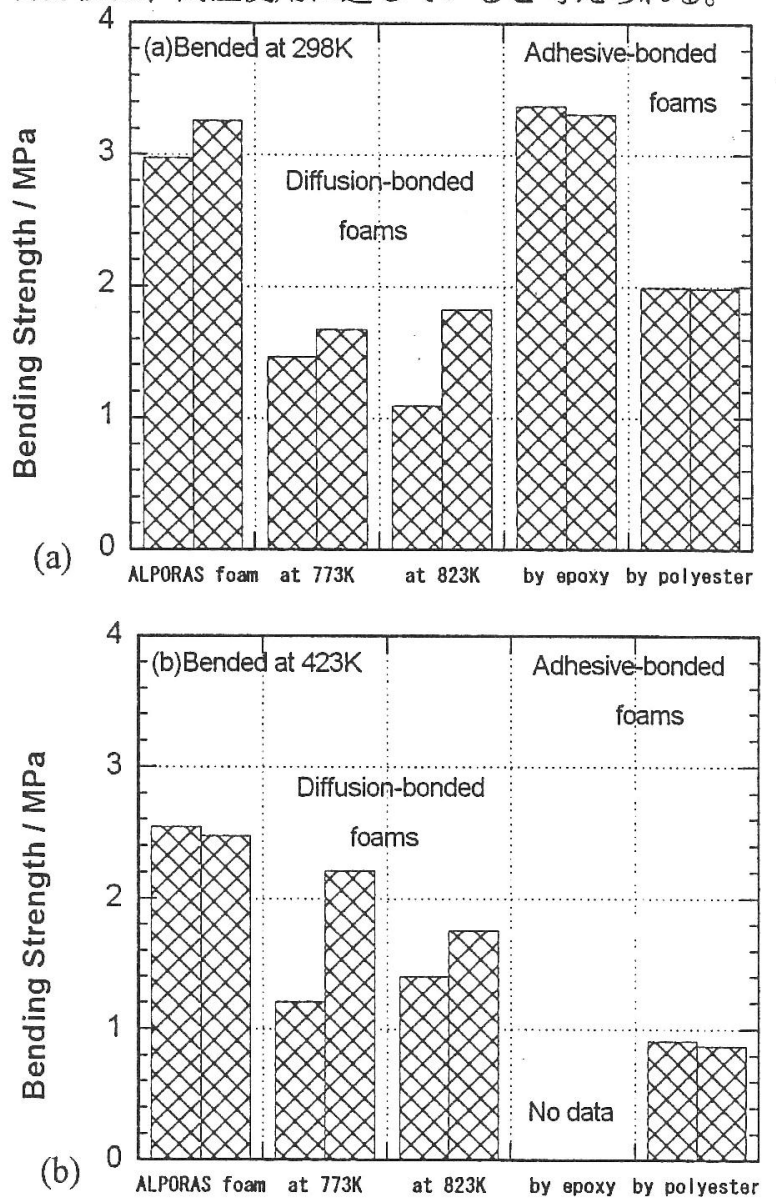

Fig.3. Results of four-point bending tests at $298 \mathrm{~K}$ (a) and $423 \mathrm{~K}(\mathrm{~b})$.

IV. CONCLUSION

超塑性 5083A1 合金をインサート材料としALPORASの 固相拡散接合を行った。曲げ試験の結果、固相拡散接 合された材料は室温において母材の約 50\%、423Kに拉 いて約 60\%の強度を示し、それは、一般のアルミニウ ム合金の大気中における接合試駼結果上同程度であっ た。今回の接合方法は他の金属フォームやセラミック スフォームにも、応用可能であると考えられる。

\section{REFERENCES}

${ }^{1}$ T. Miyoshi and M. Ito, Metal Foams and Porous Metal Structures, (1999) 125.

${ }^{2}$ K.Kannan,C.H.Jonson,andC.H.Hamolton ,Metallurgical and Materials Transaction 29A, (1998) 1211. 